\title{
EFFECT OF TEMPORARY CEMENTS ON THE BOND STRENGTH OF A RESIN CEMENT TO A PRE-HYBRIDIZED DENTIN
}

\author{
INFLUENNCIA DE CIMENTOS TEMPORÁRIOS NA RESISTÊNCIA DE UNIÃO DE \\ UM CIMENTO RESINOSO SOBRE A DENTINA PRÉ-HIBRIDIZADA
}

\author{
Márcio Ferreira LIMA ${ }^{1}$; Carolina Menezes MACIEL ${ }^{1}$; Ayla Macyelle de Oliveira CORREIA ${ }^{2}$; \\ Sandro GRIZA ${ }^{3}$; Adriano Augusto Melo de MENDONÇA ${ }^{1}$ \\ 1. Dentistry Department, Federal University of Sergipe, Aracaju, SE, Brazil; 2. Restorative Dentistry Department - State University of \\ São Paulo, São José dos Campos, SP, Brazil; 3. Post-graduation in Materials' Science and Engineering - Federal University of Sergipe, \\ São Cristóvão, SE, Brazil. adri_amm@yahoo.com.br
}

\begin{abstract}
This study assessed the bond strength of a resin cement when Immediate Sealed Dentin (ISD) was contaminated by different temporary cements applying a microshear test. Forty-eight fragments of third molar crowns were mounted in acrylic resin and worn until the dentin was exposed. The substrates were sealed with a 3-step conventional adhesive system and divided into four groups $(\mathrm{n}=12)$ : Control (without temporary cement) and three groups that used different temporary cements - Provy, RelyX Temp NE, and Provitemp. The temporary cements were removed after 7 days of storage. Resin cement RelyX ARC was applied to the contaminated substrates. Microshear bond strength was evaluated using a universal testing machine $(0.5 \mathrm{~mm} / \mathrm{min})$. Data was analyzed with ANOVA and a Dunnett post-hoc test $(\mathrm{p}<0.05)$. Additionally, three samples from each group were prepared for scanning electron microscope analysis. Means and standard deviations of microshear bond strength (MPa) were 17.96 $\pm 1.65,16.70 \pm 1.43,20.43 \pm 1.30$ and $33.75 \pm 4.72$ for Control, Provy, RelyX Temp, and Provitemp, respectively. Statistically significant difference was observed between the Control and Provitemp samples ( $\mathrm{p}=0.0002)$. Adhesive failures were dominant $(50 \%)$, followed by cohesive failures with cement (26\%), and cohesive failures with dentin (24\%). Residues of Provy and Provitemp were observed on the sealed dentin. Provitemp temporary cement sealing increased the microshear bond strength of the resin cement on dentin treated with IDS.
\end{abstract}

KEYWORDS: Dental materials. Resin cements. Bond strength. Immediate dentin sealing.

\section{INTRODUCTION}

An adhesive system is recommended for adhesive cementation of indirect restorations in dental tissue substrates (LEESUNGBOK et al., 2015; NAWAREG et al., 2015). Principles of adhesion are well-established based on the work of Nakabayashi et al. (1982), in which an interface or inter-diffusion layer, also called a hybrid layer, is created by the inter-penetration of resin monomers into enamel and dentin. This principle allows a conservative preparation of the substrates onto which the restorative materials are adhered, as well as further strengthening of the remaining dental structure (NAKABAYASHI et al., 1982).

The clinical significance of adhesive procedures is particularly relevant for indirect restorations, such as inlays, onlays, veneers, and crowns (MAGNE et al., 2007; DUMFAHRT 2000). However, adhesion success depends on the operator's knowledge of adhesion strategies and familiarity with adhesive systems (BANSAL et al., 2010). Failure at any stage of the procedure, even if the substrate is under ideal conditions, can result in adhesive failure and unwanted consequences for patients, such as post-operative sensitivity
(LEESUNGBOK et al., 2015; NIKAIDO et al., 2003). Moreover, exposure of dentin due to cavity preparation can lead to contamination of the tissue by saliva, which, in turn, can cause a reduction in bond strength. In order to overcome these problems, the Immediate Dentin Sealing (IDS) technique was developed in the early 1990s (NAWAREG et al., 2015; SULTANA et al., 2007; MAGNE; BELSER, 2002).

With the IDS technique, the bonding agent is applied onto the substrate immediately after cavity preparation (GIANINI, et al. 2015; NAWAREG et al., 2015; MAGNE; BELSER, 2002). The sealed dentinal tubules prevent the infiltration of microorganisms into pulp tissue, which minimizes pulp irritation. In addition, there is no contamination of the substrates by temporary cement residues and, thus, no problems with adhesive luting (SULTANA et al., 2007; MAROUKA et al., 2006). All bonding agents and resin cements achieve the highest bond strength values with uncontaminated dentin (MAGNE et al., 2007). However, after tooth preparation for a fixed restoration, the prepared tooth is covered with a provisional restoration, which is coated with temporary cement. The contamination of dentin 
with temporary cement has been reported to significantly reduce the bond strength values of resin cements with dentin (RIBEIRO et al., 2011; SILVA et al., 2011; FIORI-JÚNIOR et al., 2010; CARVALHO et al., 2007).

Among the temporary cements, zinc oxide eugenol (ZOE) is widely used with provisional restorative materials due to its sedative effect on sensitive teeth, ease of removal and effective sealing against leakage (HE et al., 2010). However, eugenol (2-methoxi-4-allyphenol) is a radical scavenger and may inhibit the polymerization of resin materials (GIACHETTI et al., 2012). The hydroxyl group of the eugenol molecule tends to protonize the free radicals formed during polymerization of the resin material, thereby blocking their reactivity, reducing the degree of conversion and, consequently, bond strength (BAYINDIR et al., 2003; YAP et al., 2001).

Studies show that temporary cement residues interfere with the adhesive cementation of indirect restorations (MAGNE et al., 2005; MAGNE et al., 2007). However, it is not clear whether temporary cements show similar behavior with IDS. For this reason, the present study aimed to evaluate the interference of different temporary cements on the bond strength of a resin cement with dentin that has undergone IDS.

\section{MATERIAL AND METHODS}

\section{Sample preparation}

Twenty-four crowns of extracted human third molars free of caries were used, with the approval of the Standing Committee on Ethics in Research of the Federal University of Sergipe, Brazil (Protocol 32/2012). The teeth were stored in distilled water at $4{ }^{\circ} \mathrm{C}$ and used within six months of extraction. Crowns were separated from the roots below the cement-enamel junction using a doublesided diamond saw (KG Sorensen, São Paulo, Brazil). Crowns were mesiodistally sectioned parallel to the long axis of the tooth, which produced a buccal and a lingual segment on each crown, totaling 48 samples. Specimens were mounted in polyvinyl chloride tubes and filled with acrylic resin (Jet, Artigos Odontológicos Clássico, São Paulo, SP, Brazil). Flat dentin surfaces were obtained with a silicon carbide paper (300 grit size). A smear layer was prepared using a silicon carbide paper with a grit size of 600 for 15 seconds. Concerning IDS, specimens were etched for 15 seconds with 37\% phosphoric acid (Condac 37, FGM, Joinville, SC, Brazil) and rinsed with distilled water for 15 seconds. Excess water was removed with sterile absorbent paper and a conventional 3step adhesive system was used (Adper Scotch Bond Multipurpose, 3M ESPE, St. Paul, MN). Primer was applied to dentin with a microbrush (FGM, Florianópolis, SC, Brazil), followed by a gentle air flow for 5 seconds for solvent evaporation. Two layers of adhesive were applied to the dentin and polymerized for 20 seconds with a light-curing unit (Radii-cal; SDI, Victoria, Australia). The light intensity of the unit was measured by a Demetron radiometer (Kerr Corporation. West Collins. Orange, CA, USA), which registered 1,100 $\mathrm{mW} / \mathrm{cm}^{2}$ during the entire experiment. Polymerization of the adhesive was followed by the application of an air-blocking barrier (glycerin jelly, K-Y, Johnson \& Johnson, São José dos Campos, SP, Brazil) and 10 seconds of additional light exposure with the same light unit to polymerize the oxygeninhibition layer (MAGNE et al., 2005).

The specimens were randomly divided into four groups $(n=12)$ : The Control group without temporary cement, and three groups with resin cements - Provy group (Provy, Dentsply, Petrópolis, RJ, Brazil); RelyX Temp NE group (RelyX Temp NE, 3M ESPE, St. Paul, MN), and Provitemp group (Provitemp, Biodinâmica; Ibiporã, PR, Brazil). The mixed resin cement pastes were applied inside the silicone matrix on the surface of the sealing dentin with the assistance of a Centrix syringe (Nova DFL, Rio de Janeiro, Brazil). The resin cements were used according to the manufacturers' instructions, as described in Table 1. The setting time for each material was applied according to the manufacturers' recommendations. The samples were stored at $37^{\circ} \mathrm{C}$ for seven days in a $100 \%$ humidity environment.

The temporary cements were removed with a hand scaler until the surface of the sealed dentin was clean to the naked eye. The specimens were etched for 15 seconds with $37 \%$ phosphoric acid, which was removed with a stream of water/air for 15 seconds. The surface with IDS was dried and a single new layer of adhesive (Adper Scotch Multipurpose Bond, 3M ESPE, St. Paul, MN) was applied and polymerized for 20 seconds. A silicone matrix with holes (1.6 mm diameter, $2 \mathrm{~mm}$ high) was placed over the sealed dentin. For this, diamond tips were placed around a plastic housing with added silicone (Express, 3M/ESPE, St. Paul, MN, USA), applied according to the manufacturers' instructions, and positioned around the stem of each diamond tip, resulting in an array with openings of $1.6 \mathrm{~mm}$ diameter. Adhesive resin cement (RelyX ARC, 3M ESPE, St. Paul, MN) was applied to the matrix with the aid of a Centrix syringe and light- 
cured for 40 seconds. The matrix was carefully removed and excess resin cement was trimmed with a scalpel blade. The samples were stored at $37^{\circ} \mathrm{C}$ for
24 hours in a 100\% humidity environment, in preparation for the microshear bond strength test.

Table 1. Materials used in the study, their composition and material handling.

\section{MATERIALS}

Condac 37\% (FGM) Adper Scotchbond
Multi-purpose (3M
ESPE)

Provy (Dentsply)

RelyX Temp NE (3M ESPE)
Aqueous-based gel containing 37\% Phosphoric Acid

Primer: Water (40-50\%), HEMA (35-

$45 \%)$, copolymer of acrylic and itaconic acid (10-20\%)

Adhesive: BisGMA (60-70\%) and HEMA (30-40\%)

Base: zinc oxide, oil, mineral dyes Catalyst: Eugenol, synthetic resin, wax, zinc acetate.

Base: zinc oxide, white mineral oil (petroleum), petrolatum

Catalyst: resin, reaction products with acrylic acid, nonanoic acid, silane treated silica.

Base and Catalyst: acrylate groups (70.87 \%); dimethacrylate groups; silicon dioxide, catalysts.

Provitemp
(Biodinâmica)

RelyX ARC (3M ESPE)
Bis-GMA, TEGDMA, monomers; dimethacrylate, zirconium/silica fillers

\section{HANDLING}

Base + catalyst in equal proportions. Mix base and catalyst for $30 \mathrm{~s}$ until a fine and homogeneous paste is formed.

Curing: 2 min.
Base + catalyst in equal proportions. Mix base and catalyst for $30 \mathrm{~s}$ until a fine and homogeneous paste is formed.

Curing: 4 min

\section{Base + catalyst in equal proportions. Mix base and} catalyst for $10 \mathrm{~s}$ until a fine and homogeneous paste is formed.

Curing: $1-2$ minutes.

Paste A and paste B are dispensed by Clicker in equal proportions. Hand mix for $20 \mathrm{~s}$ until a uniform color is achieved. Dual-curing system.

Light curing for $40 \mathrm{~s}$.

\section{Microshear bond strength}

The microshear bond strength test was performed with a universal testing machine (Instron 5565 , Canton, MA, USA) using a load cell of $5 \mathrm{~N}$ and speed of $0.5 \mathrm{~mm} / \mathrm{min}$. An orthodontic wire $(0.2$ $\mathrm{mm}$ thick, Morelli Orthodontics, São Paulo, SP, Brazil) was placed on half of the bonding interface circumference. The mean microshear bond strengths, expressed in $\mathrm{MPa}$, were calculated by dividing the load at fracture by the cross-sectional area of the bonding surface. Comparison of means was carried out with ANOVA and Dunnett multiplecomparison tests at a 5\% significance level.

\section{Failure mode analysis}

The fractures were examined using a stereo microscope (HMV-2, Shimadzu HMV-2, Kyoto, Japan) at 40x magnification and failure modes were classified as: adhesive failure between dentin and 
adhesive, cohesive failure in resin cement and, cohesive failure in dentin.

\section{Preparing specimens for Scanning Electron Microscopy}

In order to further analyze the effect of temporary cements on IDS, three additional fragments of each sample were prepared for scanning electron microscope (SEM) analysis (JEOL JCM-5700 Carryscope, Inc.). After IDS procedures and contamination of dentin by temporary cements, the specimens were treated as follows: $6 \mathrm{~N}$ chloride acid immersion for 15 seconds (DILLENBURG et al., 2009), 1\% sodium hypochlorite for 10 minutes, and dehydrated in ascending grades of ethanol $(30 \%, 50 \%, 95 \%$ for 30 minutes each, and $100 \%$ for 60 minutes). Specimens remained for $5 \mathrm{~min}$ on absorbent paper before being placed in semi-open receptacles that allowed alcohol to evaporate and avoided contact with air impurities. After 24 hours, specimens were placed in a desiccator with silica gel drying pearls and then positioned on stubs, spray-coated with gold, and examined by SEM at 250X magnification.

\section{RESULTS}

\section{Microshear bond strength}

The bond strength results are displayed in Table 2. According to the applied test, there was no statistically significant difference in the microshear bond strengths of the Control, Provy and Rely X Temp NE samples (Table 2). There was a statistically significant difference between the Control and Provitemp samples $(\mathrm{p}=0.0002)$.

Table 2. Means and standard deviation $(M \pm S D)$ of microshear bond strength (in MPa) for each group, and Dunnett's test comparisons.

\begin{tabular}{cr}
\hline Groups & Microshear bond stren \\
\hline & \\
Control & $17.96 \pm 1.65^{\mathbf{a}}$ \\
Provy & $16.70 \pm 1.42^{\mathbf{a}}$ \\
RelyX & $20.43 \pm 1.30^{\mathbf{a}}$ \\
Provitemp & $33.75 \pm 4.72^{\mathbf{b}}$
\end{tabular}

Groups with the same superscript letter are not statistically significantly different.

As for failure modes (Table 3), 50\% was adhesive failure between dentin and resin, $26 \%$ cohesive with resin cement, and $24 \%$ cohesive with dentin. The most frequent failures were of adhesive in the Control sample (92.3\%) and Provitemp sample $(66.6 \%)$, cohesive with resin cement in the RelyX Temp NE sample (54.5\%), and cohesive with dentin in the Provy sample $(42.8 \%)$.

Table 3. Frequency (\%) of failure mode per group. Bold-faced values indicate the most frequent failure mode in each sample.

\begin{tabular}{ccccc}
\hline FAILURE MODE & Control & Provy & RelyX & Provitemp \\
\hline $\begin{array}{c}\text { Adhesive } \\
\text { Cohesive in resin } \\
\text { cement }\end{array}$ & $\mathbf{9 2 . 3}$ & 28.6 & 9.1 & $\mathbf{6 6 . 6}$ \\
Cohesive in dentin & 7.7 & 28.6 & $\mathbf{5 4 . 5}$ & 16.7 \\
\hline
\end{tabular}

\section{Scanning Electron Microscopy (SEM)}

For the Control sample, SEM revealed some cracks in the adhesive layer due to specimen processing (Figure 1). In contrast, Provy showed some residues of temporary cement on the dentin surface (Figure 2). Differing from the Provy sample, the RelyX Temp NE sample had no temporary cement remaining on the dentin (Figure 3). However, small areas of the IDS did not show adhesive at the top end of some dentinal tubules. In the Provitemp sample, SEM showed a large amount of acrylate-based temporary cement on the dentin, adhesive at the top end of some dentinal tubules, and discontinuity of the hybrid layer (Figure 4). 


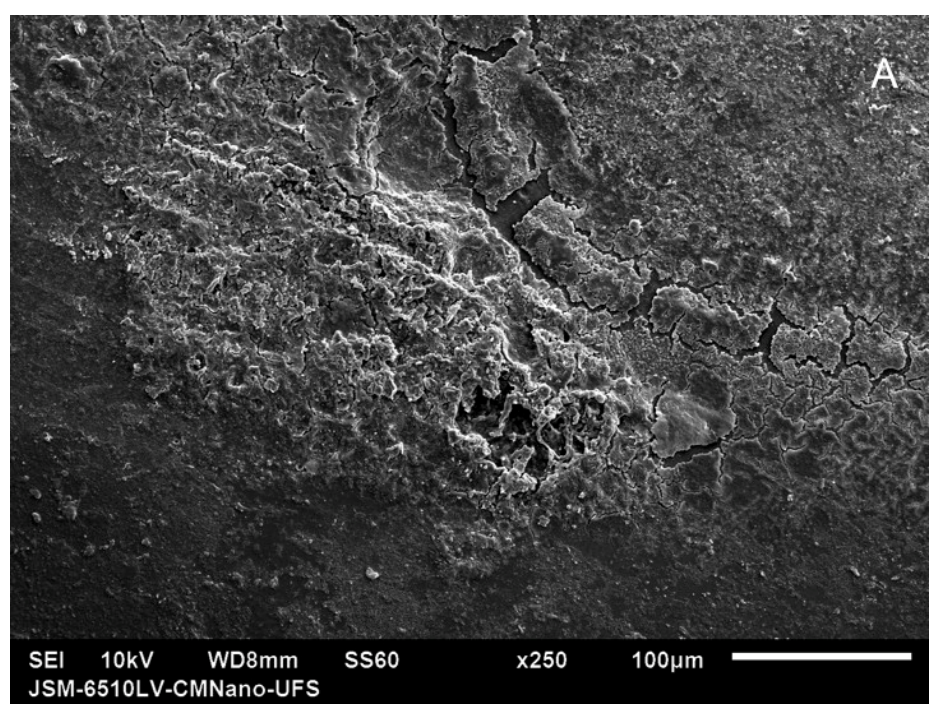

Figure 1. Control: cracks on the dentin without temporary cement.

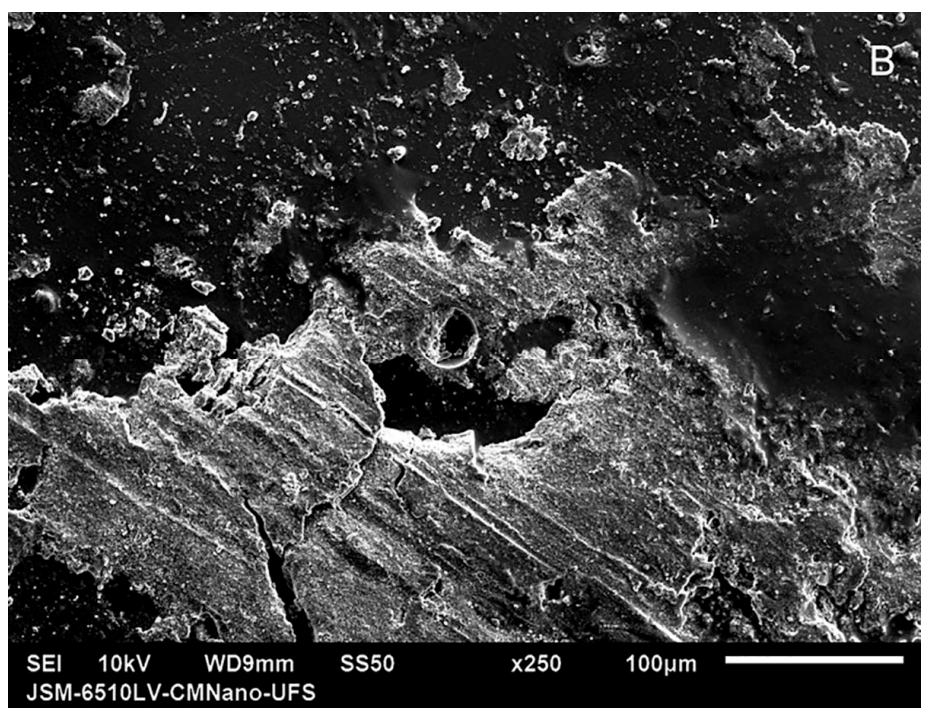

Figure 2. Provy: pre-hybridized dentin with temporary cement Provy.

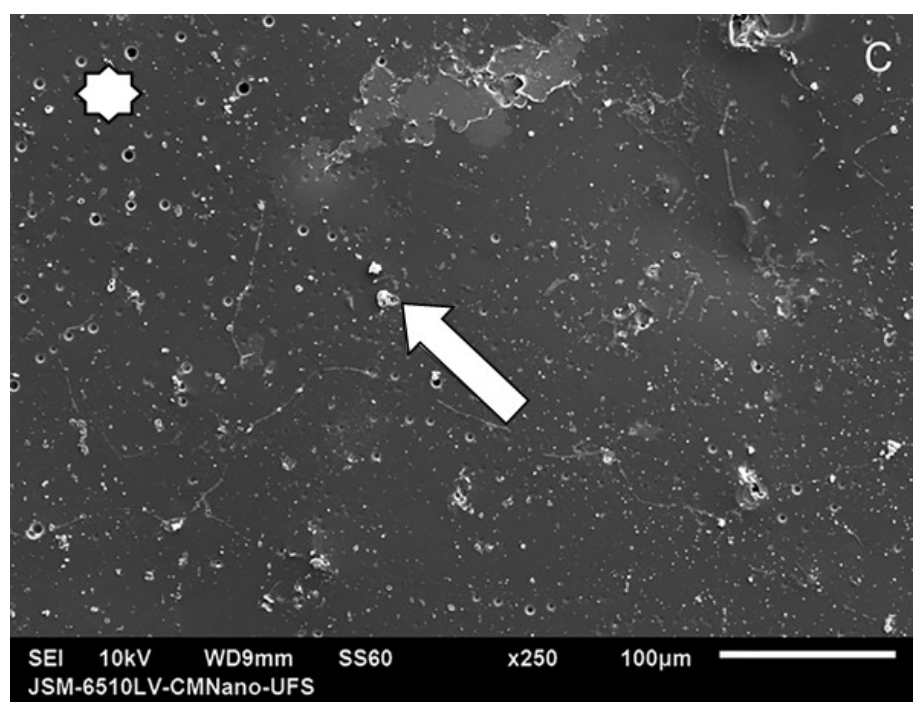

Figure 3. RelyX: dentin contaminated with temporary cement RelyX Temp NE $(\Leftarrow)$ and dentinal tubules without adhesive system $(*)$. 


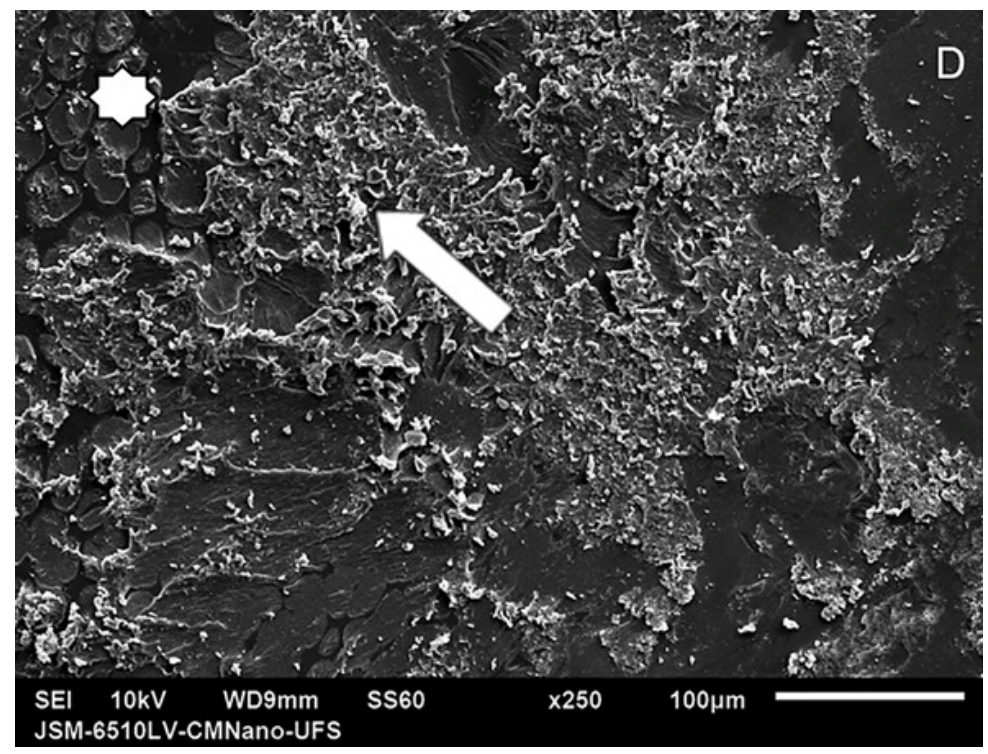

Figure 4. Provitemp: small areas with fractured hybrid layer $(*)$, and large amount of temporary cement Provitemp on the surface of the pre-hybridized dentin $(\Leftarrow)$.

\section{DISCUSSION}

Mechanical bond testing, such as microtensile bond and microshear bond tests, are required to examine the bond strength between different materials and dental substrates (ANDRADE et al., 2010; ZOHAIRY et al., 2010). The present study used the microshear bond test, which allows small areas to be tested, and it has the same advantages as the microtensile bond strength test, without the need for sectioning procedures to obtain specimens, as these laboratory procedures themselves may induce early micro-cracking within the specimen (ANDRADE et al., 2010). A better stress distribution can be accomplished in smaller specimens, using microshear bond strength testing, since the number of voids and stress-raising factors is lower than the ones that possibly occur in larger areas, such as those used for shear or tensile bond strength tests (GIACHETTI et al., 2012).

The results of the present study found no significant difference between the Control and Provy samples. Provy is a eugenol-containing temporary cement; a substance which is known to be a strong inhibitor of polymerization of resinbased materials (FIORI-JÚNIOR et al., 2010) and also able to reduce bond strength (SILVA et al., 2011; FIORI-JÚNIOR et al., 2010). Once in contact with water in the dentinal tubules, eugenalate in temporary cement is hydrolyzed, a process that releases eugenol (CARVALHO et al., 2007). This substance tends to protonate free radicals generated during the polymerization reaction (FIORI-JÚNIOR et al., 2010). As the amount of free radicals available decreases, a hybrid layer with a low degree of conversion is generated, which impairs adhesion. The fact that, in this study, the dentin was hybridized with a hydrophobic conventional 3-step adhesive system, which provides an impermeable barrier (TAY et al., 2004), might explain why the Provy sample did not differ from the Control sample. That is, this procedure might have prevented contact between the water in the dentinal tubules and the eugenol-containing temporary cement. Given that eugenol is not released, there is no interference in the polymerization of the adhesive system. This condition, associated to the highest percentage of adhesive failure mode in dentin, possibly explains the fact that there was no detected difference in the bond strength between the Control and Provy samples.

Although there is conflicting evidence regarding the effect of temporary cement on adhesion (FIORI-JÚNIOR et al., 2010; SCWARTZE et al., 2007), most studies indicate that residues of temporary materials can affect cementation of indirect restorations (SILVA et al., 2011; CARVALHO et al., 2007). Contaminants in temporary cements can impair wetting of the substrates, which impacts the bond strength of final cementation (TAKIMOTO et al., 2012). In the present study, the increase in bond strength observed in the RelyX Temp NE sample was not statistically and significantly different from that of the Control sample. Perhaps the wetting capacity of the adhesive system over the IDS might not have changed, given that a small amount of temporary cement remained adhered to the sealed dentin. In addition, the RelyX Temp NE sample showed a low percentage of adhesive failure $(9.1 \%)$, which helps 
to explain why the bond strength remained unaffected.

Despite the high percentage of adhesive failure in the Provitemp sample (66.6\%), this apparent weakened interface showed the highest average of bond strength in the study, statistically and significantly different from the control group $(p=0.0002)$. Remnants of the provisional cements used to lute provisional restorations may have influenced the bond strength of the final restoration (QANUNGO et al., 2016). Regardless of the use of a conventional or resin cement, proper cleaning of the abutment teeth is critical to avoid impairment of the etching quality on the tooth's surface, infiltration of the adhesive system, inhibition of polymerization of the resinous monomers and hence the final bonding and marginal adaptation of the restoration (DILLENBURG et al., 2009). Various authors have evaluated methods for removal of provisional cement in vitro. Reviewing these studies, it was found that the highest bond strength values were reported with soft-air abrasion (ROCCA et al., 2012), airborne particle abrasion with aluminum oxide (DILLENBURG et al., 2009. MAGNE et al., 2007. MAGNE et al., 2005) and fluoride-free pumice paste systems (DUARTE et al., 2009. MAGNE et al., 2005). However, for this study higher bond strength values are associated with temporary cement.

Although Magne and Nielsen (2009) demonstrated the interaction between different impression materials and IDS, to the best of our knowledge the present study is the first to demonstrate that acrylate-based temporary cements can interact with the hybrid layer blocked by glycerin gel. Glycerin gel is used to eliminate the oxygen-inhibited layer of the adhesive system, removing residual monomers available for polymerization (MAGNE et al, 2005). However, either blockage or elimination of the oxygeninhibited layer may not take place entirely, as some factors can affect its thickness, such as the type of adhesive and polymerization time (GHIVARI et al.,
2010. MAGNE; NIELSEN, 2009). Although the adhesive was light-cured for 20 seconds, according to the manufacturer's instructions, this time period might not have been enough to eliminate the oxygen-inhibited layer completely. Unreacted monomers and oligomers in the oxygen-inhibited layer form an inter-diffusion zone with the adjacent material, where a chemical bond is produced through copolymerization (MÜNCHOW et al., 2013). The monomers in this particular 3-step adhesive system (Adper Scotch Bond MultiPurpose) appear to have encouraged a molecular interaction with the constituents of the acrylate-based Provitemp. This interaction might have been intensified due to the period the samples were stored in this study (seven days), which might have favored a greater and better interaction between the oxygen-inhibited layer and the acrylate-based temporary cement. A stronger interaction may justify the high means of bond strength and adhesion of the temporary cement on the IDS (Figure 4).

Recent studies have been trying to determine an IDS cleaning protocol (DILLENBURG et al., 2009. MAGNE; NIELSEN, 2009). The use of acid, airborne oxide-particle abrasion and pumicing have been suggested. The results of the present study indicate that cleaning dentin contaminated by temporary cement can favor adhesion. Residues of temporary cements can result in irregular impressions, which may undermine the adaptation of indirect restorations on the IDS. Thus, future research on IDS cleaning protocols is needed, given that protecting the dentin-pulp complex cannot be compromised by different cleaning methods for dental substrates.

\section{CONCLUSION}

The IDS interaction with acrylate-based temporary cement increased the bond strength between the resin cement and the hybrid layer.

RESUMO: Este estudo investigou a influência de cimentos temporários na resistência de união de um cimento resinoso em dentina selada imediatamente. Quarenta e oito fragmentos obtidos das coroas de terceiros molares foram incluídos em tubos de PVC com resina acrílica e desgastados até exposição da dentina. Os substratos foram tratados com adesivo convencional de três passos e divididos em quatro grupos: Controle (sem cimento temporário) e três grupos usando diferentes cimentos temporários - Provy, RelyX Temp NE e Provitemp. Após sete dias, os cimentos foram removidos e o cimento RelyX ARC aplicado sobre o substrato contaminado. A resistência de união foi avaliada em uma máquina de ensaio universal $(0,5 \mathrm{~mm} / \mathrm{min})$. Os dados foram analisados pelos testes estatísticos ANOVA e Dunnet $(\mathrm{p}<0,05)$. Três amostras de cada grupo foram preparadas para análise em micróscopio eletrônico de varredura. Os valores médios e desvio padrão da resistência de união foram 17,96 $\pm 1,65,16,70 \pm 1,43,20,43 \pm 1,30$ e 33,75 $\pm 4,72$ para Controle, Provy, RelyX Temp e Provitemp, respectivamente. Diferença significativa foi observada entre os grupos Controle e Provitemp ( $\mathrm{p}=0,0002)$. Com relação ao padrão de fratura, a maioria das falhas foram adesivas $(50 \%)$, seguida por coesiva 
em cimento (26\%) e coesiva em dentina (24\%). Resíduos dos cimentos Provy e Provitemp foram observados na dentina selada. Cimento temporário Provitemp aumentou a resistência de união por microcisalhamento do cimento resinoso a dentina com IDS.

PALAVRAS-CHAVE: Cimento Resinoso. Restauração dentária temporária. Resistência ao cisalhamento.

\section{REFERENCES}

ANDRADE, A. M.; MOURA, S. K.; REIS, A.; LOGUERCIO, A. D.; GARCIA, E. J.; GRANDE, R. H. M. Evaluating resin-enamel bonds by microshear and microtensile bond strength tests: effects of composite resin. J Appl Oral Sci, Bauru, v. 18, p. 591-8, 2010. https://doi.org/10.1590/S1678-77572010000600010

BAYINDIR, F.; AKYIL, M. S.; BAYINDIR, Y. Z. Effect of eugenol and non-eugenol containing temporary cement on permanent cement retention and microhardness of cured composite resin. Dent Mater J, Tokyo, v. 22, n. 4, p. 592-9, 2003. https://doi.org/10.4012/dmj.22.592

BANSAL, S.; PANDIT, I. K.; SRIVASTAVA, N.; GUGNANI, N. Technique-sensitivity of dentin-bonding agent application: the effect on shear bond strength using one-step self-etch adhesive in primary molars: an in vitro study. J Indian Soc Pedod Prev Dent, Sawangi, v. 28, p. 183-8, 2010. https://doi.org/10.4103/09704388.73781

CARVALHO, C.N.; BAUER, J. R. B.; LOGUERCIO, A. D.; REIS, A. Effect of Zoe temporary restoration on resin-dentin bond strength using different adhesive strategies. J Esthet Restor Dent, Hamilton, v. 19, p. 14453, 2007. https://doi.org/10.1111/j.1708-8240.2007.00087.x

DILLENBURG, A. L. K.; SOARES, C. G.; PARANHOS, M. P. A.; SPOHR, A. M.; LOGUERCIO, A. D.; BURNETT, J. R. L. H. Microtensile Bond Strength of prehybridized dentin: storage time and surface treatment effects. J Adhes Dent, New Malden, v. 11, p. 231-7, 2009.

DUARTE JUNIOR, S.; FREITAS, C. R.; SAAD, J. R.; SADAN, A. The effect of immediate dentin sealing on the marginal adaptation and bond strengths of total-etch and self-etch adhesives. J Prosthet Dent, Augusta, v. 1, n. 102, p. 1-9, 2009. https://doi.org/10.1016/S0022-3913(09)00073-0

DUMFAHRT, H. Porcelain laminate veneers. A retrospective evaluation after 1 to 10 years of service: part IIclinical results. Int J Prosthodont, Berlin, v. 13, p. 9-18, 2000.

FIORI-JÚNIOR, M. F.; MATSUMOTO, W.; SILVA, R. A.; PORTO-NETO, S. T.; SILVA, J. M. Effect of temporary cements on the shear bond strength of luting cements. J Appl Oral Sci, Bauru, v. 18, p. 30-6, 2010. https://doi.org/10.1590/S1678-77572010000100007

GHIVARI, S.; CHANDAK, M.; MANYAR, N. Role of oxygen inhibited layer on shear bond strength of composites. J Conserv Dent, Kolkata-West Bengal, v. 13, p. 39-41, 2010. https://doi.org/10.4103/09720707.62635

GIACHETTI, L.; SCAMINACI, R. D.; BALDINI, M.; GORACCI, C.; FERRARI, M. Reparability of Aged Silorane With Methacrylate-Based Resin Composite: Micro-Shear Bond Strength and Scanning Electron Microscopy Evaluation. Oper Dent, Seattle, v. 37, p. 28-36, 2012. https://doi.org/10.2341/10-397-L

GIANNINI, M.; TAKAGAKI, T.; BACELAR-SÁ, R.; VERMELHO, P. M.; AMBROSANO, G. M.; SADR, A.; NIKAIDO, T.; TAGAMI, J. Influence of resin coating on bond strength of self-adhesive resin cements to dentin. Dent Mater J, Tokyo, v. 34, n. 6, p. 822-7, 2015. https://doi.org/10.4012/dmj.2015-099

HE, L. H.; PURTON, D. G.; SWAIN, M. V. A suitable base material for composite resin restorations: Zinc oxide eugenol. J Dent, Bristol, v. 38, n. 4, p. 290-5, 2010. https://doi.org/10.1016/j.jdent.2009.11.009 
LEESUNGBOK, R.; LEE, S. M.; PARK, S. J.; LEE, S. W.; LEE DO, Y., IM, B. J.; AHN, S. J. The effect of IDS (immediate dentin sealing) on dentin bond strength under various thermocycling periods. J Adv Prosthodont, Korea, v. 7, n. 3, p. 224-32, 2015. https://doi.org/10.4047/jap.2015.7.3.224

MAGNE, P.; BELSER, U. Immediate dentin bonding. In: MAGNE, P.; BELSER, U. (Eds.). Bonded porcelain restorations in the anterior dentition-a biomimetic approach. Chicago: Quintessence Publishing Co., 2002. p. 270-273, 358-363. https://doi.org/10.1016/j.prosdent.2005.10.010

MAGNE, P.; KIM, T. H.; CASCIONE, D.; DONOVAN, T. E. Immediate dentin sealing improves bond strength of indirect restorations. J Prosthet Dent, Augusta, v. 94, p.511-9, 2005.

https://doi.org/10.1016/S0022-3913(09)60178-5

MAGNE, P.; NIELSEN, B. Interactions between impression materials and immediate dentin sealing. J Prosthet Dent, Augusta, v. 102, p. 298-305, 2009.

MAGNE, P.; SO, W. S.; CASCIONE, D. Immediate dentin sealing supports delayed restoration placement. J Prosthet Dent, Augusta, v. 98, p; 166-74, 2007.

MARUOKA, R.; NIKAIDO, T.; IKEDA, M.; ISHIZUKA, T.; FOXTON, R. M. Coronal leakage inhibition in endodontically treated teeth using Resin-Coating technique. Dent Mater J, Tokyo, v. 25, p. 97-103, 2006. https://doi.org/10.4012/dmj.25.97

MÜNCHOW, E. A.; VALENTE, L. L.; PERALTA, S. L.; FERNÁNDEZ, M. R.; LIMA, G. D. A. S.; PETZHOLD, C. L.; PIVA, E.; OGLIARI, F. A. 1,3-Diethyl-2-thiobarbituric acid as an alternative coinitiator for acidic photopolymerizable dental materials. J Biomed Mater Res B Appl Biomater, Hoboken, v. 101, p. 1217-21, 2013. https://doi.org/10.1002/jbm.b.32933

NAKABAYASHI, N.; KOJIMA, K.; MASUHARA, E. The promotion of adhesion by the infiltration of monomers into tooth substrates. J Biomed Mater Res, Cleveland, v. 16, p. 265-73, 1982.

https://doi.org/10.1002/jbm.820160307

NAWAREG, M. M.; ZIDAN, A. Z.; ZHOU, J.; CHIBA, A.; TAGAMI, J.; PASHLEY, D. H. Adhesive sealing of dentin surfaces in vitro: A review. Am J Dent, Cordova, v. 28, n. 6, p. 321-32, 2015.

NIKAIDO, T.; NAKAOKI, Y.; OGATA, M.; FOXTON, R.; TAGAMI, J. The Resin-coating technique. Effect of a single-step bonding system on dentin bond strength. J Adhes Dent, New Malden, v. 5, p. 293-300, 2003.

QANUNGO, A.; ARAS, M. A.; CHITRE, V.; MYSORE, A.; AMIN, B.; DASWANI, S. R. Immediate dentin sealing for indirect bonded restorations. J Prosthodont Res, Japan, v. 60, n. 4, p. 240-9, 2016.

https://doi.org/10.1016/j.jpor.2016.04.001

RIBEIRO, J. C. V.; COELHO, P. G.; JANAL, M. N.; SILVA, N. R. F. A.; MONTEIRO, A. J.; FERNANDES, C. A. O. The influence of temporary cements on dental adhesive systems for luting cementation. J Dent, Bristol, v. 39, p. 255-62, 2011. https://doi.org/10.1016/j.jdent.2011.01.004

ROCCA, G. T.; GREGOR, L.; SANDOVAL, M. J.; KREJCI, I.; DIETCHI, D. In vitro evaluation of marginal and internal adaptation after occlusal stressing of indirect class II composite restorations with different resinous bases and interface treatments. Post-fatigue adaptation of indirect composite restorations. Clin Oral Investig, Berlin, v. 5, n. 16, p. 1385-93, 2012. https://doi.org/10.1007/s00784-011-0632-x

SCHWARTZER, E.; COLLARES, F. M.; OGLIARI, F. A.; LEITUNE, V.; SAMUEL, S. Influence of zinc oxide-eugenol temporary cement on bond strength of an all-in-one adhesive system to bovine dentin. Braz J Oral Sci, Piracicaba, v. 6, p. 1423-7, 2007. 
SILVA, J. P.; QUEIROZ, D. M.; AZEVEDO, L. H.; LEAL, L. C.; RODRIGUES, J. L.; LIMA, A. F.; MARCHI, G. M.; BRITO-JÚNIOR, M.; FARIA-E-SILVA, A. L. Effect of eugenol exposure time and postremoval delay on the bond strength of a self-etching adhesive to dentin. Oper Dent, Seattle, v. 36, p. 66-71, 2011. https://doi.org/10.2341/10-115-LR

SULTANA, S.; NIKAIDO, T.; MATIN, K.; OGATA, M.; FOXTON, R. M.; TAGAMI, J. Effect of resin coating on dentin bonding of resin cement in class II cavities. Dent Mater J, Tokyo, v. 26, p. 508-13, 2007. https://doi.org/10.4012/dmj.26.506

TAKIMOTO, M.; ISHII, R.; LINO, M.; SHIMIZU, Y.; TSUJIMOTO, A.; TAKAMIZAWA, T.; ANDO, S.; MIYAZAKI, M. Influence of temporary cement contamination on the surface free energy and dentine bond strength of self-adhesive cements. J Dent, Bristol, v. 40, p. 131-8, 2012.

https://doi.org/10.1016/j.jdent.2011.11.012

TAY, F. R.; CARVALHO, R. M.; PASHLEY, D. H. Water movement across bonded dentin - too much of a good thing. J Appl Oral Sci, Bauru, v. 12, p. 12-25, 2004. https://doi.org/10.1590/S1678-77572004000500003

YAP, A. U.; SHAH, K. C.; LOH, E. T.; SIM, S. S.; TAN, C. C. Influence of eugenol-containing temporary restorations on bond strength of composite to dentin. Oper Dent, Seattle, v. 26, n. 6, p. 556-61, 2001.

ZOHAIRY, A. A.; SABER, M. H.; ABDALLA, A. I.; FEILZER, A. J. Efficacy of microtensile versus microshear bond testing for evaluation of bond strength of dental adhesive systems to enamel. Dental Mater, Copenhagen, v. 26, p. 848-54, 2010. https://doi.org/10.1016/j.dental.2010.04.010 